\title{
Big Data Educational Portal for Small and Medium Sized Enterprises (SMEs)
}

\author{
Chekfoung Tan \\ School of Computing and Engineering \\ University of West London \\ Ealing, London, W5 5RF \\ $+44(0) 2082312932$ \\ Chekfoung.Tan@uwl.ac.uk
}

\author{
Mohammed Haji \\ School of Computing and Engineering \\ University of West London \\ Ealing, London, W5 5RF
}

sharafle1@gmail.com

\begin{abstract}
Big Data refers to the massive amount of data generated from IT systems, sensors, and mobile devices. The values of big data are achieved by descriptive, predictive and prescriptive analytics. Small and Medium Sized Enterprises (SMEs) play a significant role in contributing to economic development. Big data is seen as a strategic and innovative tool for SMEs to stay competitive in the marketplace. However, there is lack of research in studying the value of big data to SMEs. Moreover, due to the shortage of quality learning platforms, SMEs have limited understanding of the potential benefits big data offers their businesses. This research aims to propose an educational portal of big data for SMEs by incorporating the pedagogy aspects. The research is underpinned by design science research. The portal contributes theoretically and methodologically by deriving the design knowledge of such portal and practically by increasing big data knowledge among SMEs.
\end{abstract}

\section{CCS Concepts}

- Applied Computing $\rightarrow$ E-learning

\section{Keywords}

Big Data; Small and Medium Sized Enterprises; Educational Portal; Design Science Research; Pedagogy

\section{INTRODUCTION}

Big data refers to datasets that are too large for traditional dataprocessing systems to capture, store, manage and analyze [1, 2]. Big data is commonly known with four characteristics [3]: Volume, Velocity, Variety and Veracity. Volume describes the amount of data stored. Variety refers to the different types of data both structured and unstructured. Structured data is data that has a specific format and can be directly processed with computing equipment [4] whereas unstructured data is data that does not have a specific format, such as images and audio files [3]. Velocity describes how fast the data is being transmitted, processed, analyzed and understood by the end users to perform certain tasks, for example, decision making. Veracity refers to the quality or trustworthiness of the data.

Permission to make digital or hard copies of all or part of this work for personal or classroom use is granted without fee provided that copies are not made or distributed for profit or commercial advantage and that copies bear this notice and the full citation on the first page. Copyrights for components of this work owned by others than ACM must be honored. Abstracting with credit is permitted. To copy otherwise, or republish, to post on servers or to redistribute to lists, requires prior specific permission and/or a fee. Request permissions from Permissions@acm.org.

BDIOT2017, December 20-22, 2017, London, United Kingdom

(C) 2017 Copyright is held by the owner/author(s). Publication rights licensed to ACM.

ACM ISBN 978-1-4503-5430-1/17/12 ..\$15.00

https://doi.org/10.1145/3175684.3175688
The small and medium sized enterprises (SMEs) are categorized into medium, small and micro sizes, based on the number of employees and turnover. A medium SME has less than 250 employees and turnover less than $€ 50$ million, a small SME has less than 50 employees and turnover less than $€ 10$ million, and a micro SME has less than 10 employees and the turnover is less than $€ 2$ million [11]. SMEs contribute significantly towards the economy, especially in job creation and economic growth. According to EuropeanCommission [5], SMEs contribute 56\% of the overall GDP in the EU and employ $67 \%$ of the workers in the private sector. Hence, SMEs play a vital role in the economic development of a region. Due to the rivalry competition, constant changes brought by globalization and technology revolution, SMEs are seeking innovative approach in order to grow the business by improving their performances including the application of big data $[6,7]$.

However, there is limited research in studying the values of big data to SMEs. Most SMEs are unaware of how big data could help them in achieving competitive advantages, such as innovating their services and products via data [8]. According to [9], a practical educational portal enables SME owners or managers to gain new knowledge that is strategically focused to the organization. Pedagogy aspect is vital when designing the content and features for an educational portal [9]. There are many online sources discussing big data, however, most of the educational portals employed by SMEs are yet to achieve good quality [7], This is due to the lack of pedagogy planning, especially in the context of big data. Hence, the aim of this paper is to propose a big data educational portal by incorporating pedagogy aspects. The paper is structured as follows: Section 2 reviews the related literature, Section 3 illustrates the research methodology, Section 4 describes a prototype of the big data educational portal, Section 5 describes the evaluation results of the educational portal, and Section 6 discusses the contributions, limitations and concludes the research with future work.

\section{THEORETICAL BACKGROUND}

\subsection{Big Data Values to SMEs}

The value of big data is unlocked through analytics where the data is collected from various sources, processed and presented with an insight [10]. There are three types of analytics [11]: descriptive analytics, predictive analytics, and prescriptive analytics. Descriptive analytics use historical data and quantitative tool to understand the patterns of the existing situation. Predictive analytics adopt simulation models to generate scenarios based on historical data to predict the future. Prescriptive analytics employ planned and quantitative analyses of real time data that may trigger events and recommend the course of action. There are five key values brought by big data to SMEs: 1) driving product or service innovation $[8,12]$, where customers' requirements and 
their behavior could be understood better in order to improve products or services, 2) gaining competitive advantages [13, 14], where market or consumers' reactions could be studied better, rivals, new entrants or threats are identified hence better positioning the organization in the market, 3) increase operational efficiencies $[15,16]$, where business services can be improved in order to address strategic needs, 4) make informed decision [1719], where specific information is identified to improve targeted decision processes which in turns enabling organizational learning, and 5) foster business collaborations and partnership [adapted from 20], where capabilities of potential partners are studied in order to form a digital business ecosystem.

\subsection{Pedagogy Aspects of Educational Portal}

Educational portal facilitates learning approach by using information and communication technology (ICT) where learners are distributed across the internet [21, 22]. The key factors that should be considered when developing an educational portal are [9, 22-26]: 1) enable learners to communicate their ideas and information among each other, 2) offer collaborative access to essential documents to learners, 3 ) enable instructors and peers to provide feedback to learners, and 4) ensure contact between training provider and learners. Pedagogy aspect in educational portal provides an efficient delivery of teaching content and knowledge based on learners' need for the real life situation [9]. The three key dimensions of pedagogy are [27]: 1) delivery mechanism, providing reading or administrative materials online to complete the content delivery (e.g. static or dynamic online content), 2) class size, and 3) approach to content, refer to the process of distributing the teaching content (e.g. providing static material via interactive online activities that are not possible to achieve in the face-to-face learning experience). A clear pedagogy for an educational portal should include Bloom's taxonomy [28] which consists of comprehension, application, analysis, synthesis and evaluation aspects whenever it is applicable. The comprehension level ensures learners are able to understand the provided knowledge, the application and analysis level where learners are asked to analyze and solve a problem by applying the knowledge that they have learned, and the synthesis and evaluation level enables learners to use the given knowledge to either create new theories, draw new conclusions or make predictions.

\section{RESEARCH METHODOLOGY}

Design science research (DSR) is based on problem solving paradigm [29]. There are seven principles in DSR. are: 1) design as an artefact, where a viable artefact (constructs, model, method, instantiation) will be produced, 2) problem relevance, where technology based solutions to important and relevant business problems will be developed, 3) design evaluation, where artefact's utility, quality and efficacy will be evaluated rigorously, 4) research contributions, where clear and verifiable contributions are provided, 5) research rigor, where rigorous methods in both the construction and evaluation of design are applied, 6) design as a search process, where an effective solution to a problem will be discovered, and 7) communication of research, where artefact will be presented effectively to the technology and management oriented audience. DSR is adopted in this research as this research aims to develop a solution that addresses a practical business problem. Table 1 illustrates the research design.

Table 1. Research Design Underpinned by DSR

\begin{tabular}{|l|l|}
\hline $\begin{array}{l}\text { Research } \\
\text { Design }\end{array}$ & Application of DSR Principles \\
\hline
\end{tabular}

\begin{tabular}{|c|c|}
\hline $\begin{array}{l}\text { Stage 1: } \\
\text { Identify } \\
\text { research } \\
\text { problems }\end{array}$ & $\begin{array}{l}\text { Problem relevance, where this research aims to } \\
\text { develop a technology based solution (the } \\
\text { education portal) to address the research } \\
\text { problem. }\end{array}$ \\
\hline $\begin{array}{l}\text { Stage 2: } \\
\text { Conduct } \\
\text { literature } \\
\text { review }\end{array}$ & $\begin{array}{l}\text { Design as a search process, where this research } \\
\text { suggests the education portal as the solution to } \\
\text { the research problem through intensive } \\
\text { literature review (see Section } 2 \text { ). }\end{array}$ \\
\hline $\begin{array}{l}\text { Stage } 3 \text { : } \\
\text { Collect and } \\
\text { analyse data }\end{array}$ & $\begin{array}{l}\text { Research rigour, where rigorous methods were } \\
\text { applied to ensure the validity and utility of the } \\
\text { solution [30]. Primary data were collected via } \\
\text { semi-structured interview and secondary data } \\
\text { were collected from the literature and industry } \\
\text { reports. Semi structured interviews [31] have } \\
\text { been conducted to four SMEs owners in varied } \\
\text { industry such as catering, lodging (bed and } \\
\text { breakfast), retail and investment projects. Prior } \\
\text { to commencing the interview, SME owners } \\
\text { were offered an information sheet that included } \\
\text { the values brought by big data to SMEs. The } \\
\text { interview questions were structured various } \\
\text { themes and the interview data was analysed via } \\
\text { descriptive analysis [32]. Table } 2 \text { show the key } \\
\text { interview questions and summary results } \\
\text { collected from the SME owners. The data from } \\
\text { semi structured interviews were applied to } \\
\text { validate the needs of the big data educational } \\
\text { portal for SMEs (see Section } 3.2 \text { ) and the } \\
\text { secondary data (e.g. academic literature and } \\
\text { industry reports) were used to populate the } \\
\text { content of the educational portal. In addition, } \\
\text { evaluation survey was conducted (see Stage } 5 \text { ). }\end{array}$ \\
\hline $\begin{array}{l}\text { Stage 4: } \\
\text { Develop big } \\
\text { data } \\
\text { educational } \\
\text { portal }\end{array}$ & $\begin{array}{l}\text { Design as an artefact, where a prototype of the } \\
\text { educational portal was developed (see Section } \\
\text { 4). }\end{array}$ \\
\hline $\begin{array}{l}\text { Stage 5: } \\
\text { Conduct } \\
\text { evaluation } \\
\text { survey }\end{array}$ & $\begin{array}{l}\text { Design evaluation, where evaluation survey } \\
\text { was conducted in order to ascertain the } \\
\text { proposed solution fulfils SMEs' needs (see } \\
\text { Section 5). }\end{array}$ \\
\hline $\begin{array}{l}\text { Stage 6: } \\
\text { Critical } \\
\text { discussion }\end{array}$ & $\begin{array}{l}\text { Research contributions and communication of } \\
\text { research, where the contributions were } \\
\text { discussed and research outcomes were } \\
\text { presented in the University annual project } \\
\text { presentation (see Section 6). }\end{array}$ \\
\hline
\end{tabular}

Table 2. Key Interview Questions and Summary Results

\begin{tabular}{|c|c|}
\hline Themes & $\begin{array}{l}\text { Level of awareness (current state of art of big } \\
\text { data development) }\end{array}$ \\
\hline \multicolumn{2}{|c|}{$\begin{array}{l}\text { Key Questions } \\
\text { How SMEs have changed due to big data? } \\
\text { What are the purpose of big data to your business? } \\
\text { What are the challenges for you to implement big data? }\end{array}$} \\
\hline $\begin{array}{l}\text { Key Resu } \\
\text { SMEs hay } \\
\text { due to big } \\
\text { mobile tec } \\
\text { anywhere } \\
\text { SME own } \\
\text { implemen } \\
\text { provide th } \\
\text { The chall }\end{array}$ & $\begin{array}{l}\text { hanged in terms of the way in managing business } \\
\text { ta especially the proliferation of internet and } \\
\text { ologies where data can be collected anytime and } \\
\text { are not fully aware of how big data could be } \\
\text { as they rely on the third party providers to } \\
\text { xpertise. } \\
\text { es of SMEs in implementing big data is the lack of }\end{array}$ \\
\hline
\end{tabular}




\begin{tabular}{|c|c|}
\hline \multicolumn{2}{|c|}{ knowledge as they rely on the third party IT supplier. } \\
\hline Themes & Validity \\
\hline \multicolumn{2}{|c|}{$\begin{array}{l}\text { Key Questions } \\
\text { Do you think the big data educational portal will be benefit for } \\
\text { you and your business? }\end{array}$} \\
\hline \multicolumn{2}{|c|}{$\begin{array}{l}\text { Key Results } \\
\text { The big data educational portal will be useful for SMEs by } \\
\text { increasing their knowledge about the value of big data to their } \\
\text { businesses. } \\
\text { The portal will minimize their reliance to the IT suppliers when } \\
\text { it comes to big data implementation. }\end{array}$} \\
\hline Themes & Learning Content \\
\hline \multicolumn{2}{|c|}{$\begin{array}{l}\text { Key Questions } \\
\text { What would you like to see in the big data educational portal? }\end{array}$} \\
\hline \multicolumn{2}{|c|}{$\begin{array}{l}\text { Key Results } \\
\text { All four interviewees explained that they would like to know } \\
\text { more about big data itself, and its values to their businesses } \\
\text { (e.g. the benefits of big data). }\end{array}$} \\
\hline
\end{tabular}

\section{BIG DATA EDUCATIONAL PORTAL FOR SMES}

The educational portal is developed from the primary data (the interview data) and secondary data (academic literature and industry reports). The portal proposed in this paper highly focusses on its content feature which is driven by the pedagogy aspects from Bloom's taxonomy (see Figure 1). The educational portal offers niche knowledge of big data for the SMEs. The comprehension feature is reflected in the educational portal by having the fundamental content of big data such as the benefits and risks, the application and analysis feature is reflected by showing how big data could be implemented in the SMEs and the synthesis and application feature is demonstrated through an evaluation function that allows SME owners to measure their level of knowledge in terms of big data. Interactive media such as Youtube videos are embedded in order to enhance the learning experience of the SME users. The portal is equipped with member registration feature.

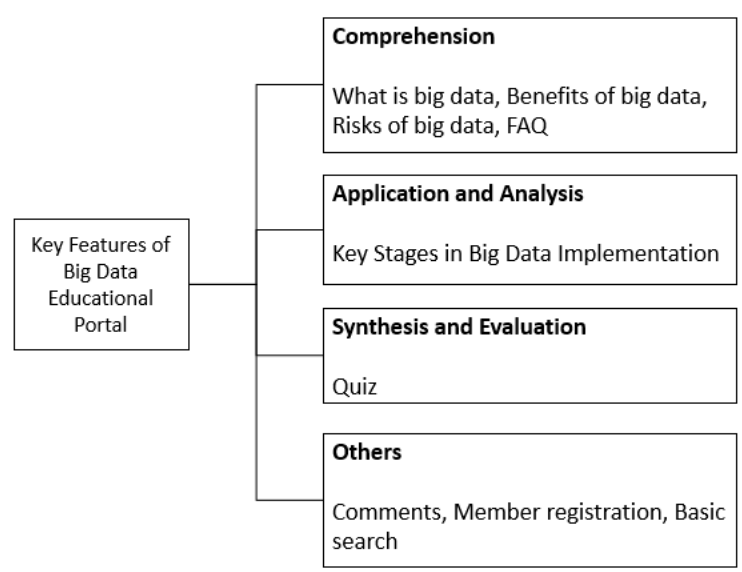

Figure 1. Features of Big Data Educational Portal
Moreover, the comment feature (see Figure 2) allows the learners (SME owners) to communicate with the instructor (the portal owner / training provider) and for the instructor to provide feedback on any queries posted by the learners. This feature enables SME owners to share their knowledge and experience which is beneficial to the whole SME community who subscribes to the educational portal. In addition, the portal has a basic keyword search functionality on the FAQ page. Basic navigation is incorporated in the portal. Figure 3 shows the prototype of the big data educational portal.

\section{2 comments}

\section{Q Leave a message

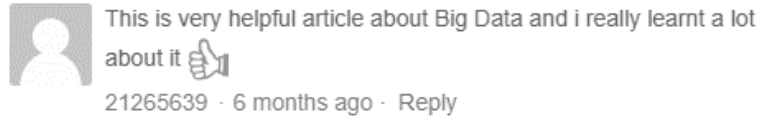 \\ $21265639 \cdot 6$ months ago $\cdot$ Reply \\ Will try our best to add more updates about this article and many more \\ $21265639 \cdot 6$ months ago

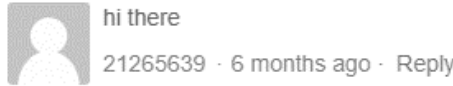

Figure 2. The "Comments" Feature

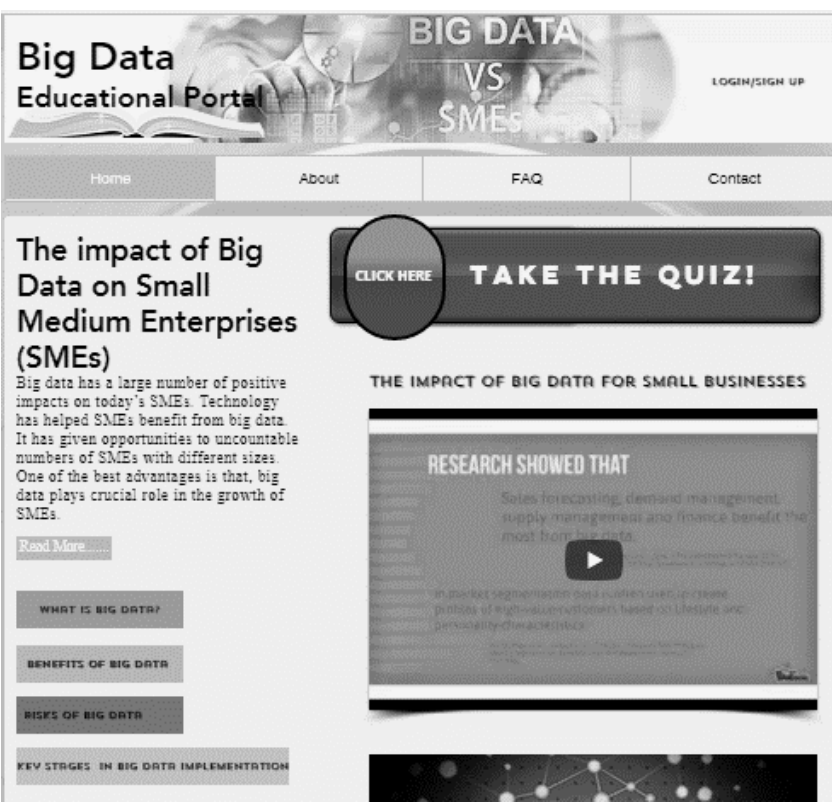

Figure 3. Prototype of the Big Data Educational Portal

\section{PORTAL EVALUATIONS}

An evaluation survey (see Table 3) was conducted in order to evaluate the validity and utility aspect of the educational portal [after 30]. The validity aspect ensures the educational portal proposed by the literature works correctly and the utility aspect ascertains the educational portal addresses SMEs needs in 
learning big data. The utility aspect includes questions such as 1) user's satisfaction, as it is crucial for SME owners to adopt the education portal [33], 2) portal interactivity, includes factors such as appearance (the design of the portal), content (quality of the materials), accessibility (the currency of the materials in the portal and that it is accessible to learners anytime and anywhere), responsiveness (the interaction between learners and instructors) and learnability (how easy the portal is for learners to learn about big data) [34], and 3) perceived usefulness, if the educational portal is useful for the SMEs and perceived ease of use, if the educational portal is user friendly quoted from the technology acceptance model [35]. An evaluation survey was distributed to a number of SME owners and 11 responses were received.

Overall, the respondents are satisfied with the features derived by the pedagogy in the educational portal. One respondent suggested that the collaborative features "should include conference call plugins so that the SME community can exchange ideas". In terms of the portal interactivity features, most of the respondent preferred the appearance of the website, followed by accessibility, content, learnability, and responsiveness. Respondents suggested that "The portal is easy to navigate" and "The portal has good background information". They also feel that the educational portal is easy to use. In average, the respondents visited 5-8 pages in the portal which indicates that page navigation in the portal is easy. In addition, the respondents find that the portal is useful for them as SME owners. One respondent commented that "The FAQS page is really useful as it answers some significant questions related to Big Data".

Table 3. Portal Evaluation Survey

\begin{tabular}{|l|l|}
\hline $\begin{array}{l}\text { Utility } \\
\text { Aspect }\end{array}$ & Questions \\
\hline $\begin{array}{l}\text { User's } \\
\text { Satisfaction }\end{array}$ & $\begin{array}{l}\text { How satisfied are you with this website? } \\
\text { Do you experience any problems using this } \\
\text { website? }\end{array}$ \\
\hline $\begin{array}{l}\text { Portal } \\
\text { Interactivity }\end{array}$ & $\begin{array}{l}\text { What did you like the most about this website? } \\
\text { What you would like to improve on this } \\
\text { website? }\end{array}$ \\
\hline $\begin{array}{l}\text { Perceived } \\
\text { Usefulness }\end{array}$ & $\begin{array}{l}\text { Do you think that this website is useful for } \\
\text { Approximately how many pages did you } \\
\text { browse during this visit? }\end{array}$ \\
\hline $\begin{array}{l}\text { Perceived } \\
\text { Ease of Use }\end{array}$ & $\begin{array}{l}\text { What do you think about the features of this } \\
\text { website? } \\
\text { Do you think that this website is easy to use? }\end{array}$ \\
\hline Others & $\begin{array}{l}\text { Please provide your suggestions in order to help } \\
\text { us to improve the big data educational portal } \\
\text { (Any other comments) }\end{array}$ \\
\hline
\end{tabular}

The respondents suggested a few improvements in terms of portal interactivity in terms of the content such as "giving an example of real cases could increase the understanding of the users", "different level of big data lessons to be included" and "more explanations of the technical terms". In terms of the perceived usefulness, the respondents feel that there should contain a secured course registration feature so that SME owners can register in order to learn more. Hence, the results have suggested that SMEs can benefit from this educational portal. The educational portal is therefore valid and useful in the context of SMEs.

\section{DISCUSSIONS AND CONCLUSIONS}

This paper has delivered a big data educational portal for SMEs. The portal incorporates pedagogy aspects when designing the key features. The pedagogy design supports the fundamental content and features of the educational portal such as the definition, benefits, risks and key implementation stages of big data. The research is underpinned by design science research, with the focus being to address the lack of understanding about big data among the SMEs. The portal enables SMEs to learn in a more collaborative and efficient manner. The main difference of this portal compared to any other online learning sources, is that the features and content are derived by a structured pedagogy. In addition, this portal consists of domain specific big data knowledge relevant to SMEs.

\subsection{Contributions}

This research possesses theoretical, methodological and practical contributions. From the theoretical and methodological perspectives, this research has employed a pedagogy design for the development of the big data educational portal in the context of SMEs. This research has demonstrated the adoption of pedagogy aspects in informing the system development of an educational portal. It underpins the core pedagogy features for future research along this line. Moreover, this research has highlighted the importance of pedagogy aspects and how to integrate the features in an educational portal in the context of SMEs.

From the practical perspective, the educational portal has enabled SME owners to have a better understanding about big data, and the value it can bring to their business. The practical knowledge in the portal enables SME owners to achieve strategic advantages, such as innovating their products and services by employing big data. Furthermore, the prototype of the educational portal will be open to the public and will be accessible anytime and anywhere. The Comments feature in the portal enables the SME community to learn from each other and creates SME networks that foster future collaboration opportunities. Furthermore, the training providers can benefit from the proposed pedagogy in the context of big data for SMEs in the online courses.

\subsection{Limitations}

There are limitations identified in this research after critically evaluating the big data educational portal. One of the limitations is related to the content. As the educational portal proposed here is prototypical, the materials produced are static and case examples have not been incorporated. The materials are updated upon request from the learners (the SME owners). From the system perspective, a few features such as member subscription based on different course level, peer feedback among learners and between learners and instructors, communication tools such as conference call plugins (e.g. Skype) are yet to be developed.

\subsection{Future Work}

The evaluation of this research suggests that the aim of this research has been achieved. As for the future work, more data will be collected from the SMEs across various fields in order to enrich the content and features of the big data educational portal. In addition, more case studies from academic literature and industry reports will be collected in order to enrich the practicality of the portal. Furthermore, the pedagogy of the big data for SMEs will be further enhanced, so that various levels of courses (e.g. foundation, intermediate, and advance) could be created. The enhanced pedagogy has high potential in contributing to developing Massive Open Online Courses (MOOCs). 
In addition, other features will be further developed as part of the portal enhancement. A member registration feature based on different course levels, will be integrated, so that learners (the SME owners) can develop their own community, design their own learning plan, track their learning progress and determine their own contact hours with the instructors. A virtual classroom feature will be incorporated in order to enable learners to study together. Furthermore, a content management feature will be developed to enable the instructor to update and upload materials in real time.

\section{REFERENCES}

[1] Manyika, J., Chui, M., Brown, B., Bughin, J., Dobbs, R., Roxburgh, C. and Byers, A. H. Big data: The next frontier for innovation, competition, and productivity. McKinsey Global Institute, US, 2011.

[2] Provost, F. and Fawcett, T. Data Science for Business. O'Reilly Media, New York, City, 2013.

[3] Zikopoulos, P., Parasuraman, K., Deutsch, T., Giles, J. and Corrigan, D. Harness the Power of Big Data The IBM Big Data Platform. McGraw Hill Professional, 2012.

[4] Baars, H. and Kemper, H.-G. Management support with structured and unstructured data-an integrated business intelligence framework. Information Systems Management, 25, 2 (2008), 132-148.

[5] EuropeanCommission. Putting Small Businesses First Europe is Good for SMEs, SMEs are Good for Europe. European Commission Publications Office, Luxembourg, 2008.

[6] Brown, B., Chui, M. and Manyika, J. Are you ready for the era of 'big data'. McKinsey Quarterly, 4, 1 (2011), 24-35.

[7] Hamburg, I., Engert, S., Anke, P., Marin, M. and im IKM Bereich, E.-C. A. Improving e-learning 2.0-based training strategies of SMEs through communities of practice. learning, 2 (2008), 610-012.

[8] Sen, D., Ozturk, M. and Vayvay, O. An Overview of Big Data for Growth in SMEs. Procedia-Social and Behavioral Sciences, 235 (2016), 159-167.

[9] Šimúth, J. and Hvorecký, J. E-Pedagogy as a Basis for ELearning. In Proceedings of the International Conference on e-Learning (Bratislava, Slovakia, 2016)

[10] Power, D. Using Big Data for Analytics and Decision Support (2013).

[11] Raghupathi, W. and Raghupathi, V. An Overview of Health Analytics. J Health Med Informat, 4, 132 (2013), 2.

[12] Kiron, D., Prentice, P. K. and Ferguson, R. B. Innovating with analytics. MIT Sloan Management Review, 54, 1 (2012), 47.

[13] Charles, V. and Gherman, T. Achieving competitive advantage through big data. Strategic implications. MiddleEast Journal of Scientific Research, 16, 8 (2013), 1069-1074.

[14] Kamioka, T. and Tapanainen, T. Organizational Use of Big Data and Competitive Advantage-Exploration of Antecedents. City, 2014.

[15] Arcondara, J., Himmi, K., Guan, P. and Zhou, W. Value Oriented Big Data Strategy: Analysis \& Case Study. In Proceedings of the 50th Hawaii International Conference on System Sciences (Hawaii, USA, 2017)

[16] Tan, C. Organisational Semiotics Inspired Abductive Methodology of Developing Information Architecture for Healthcare Organisations. University of Reading, 2015.

[17] Le Dinh, T., Thuong-Cang, P. and Bui, T. Towards an Architecture for Big Data-Driven Knowledge Management Systems. In Proceedings of the 22nd Americas Conference on Information Systems (AMCIS2016) (San Diego, USA, 2016)

[18] Brynjolfsson, E., Hitt, L. M. and Kim, H. H. Strength in numbers: How does data-driven decisionmaking affect firm performance? , Sloan School of Management, MIT, Cambridge, MA, USA, 2011.

[19] Davenport, T. H. Business intelligence and organizational decisions. International Journal of Business Intelligence Research (IJBIR), 1, 1 (2010), 1-12.

[20] Sun, L., Tan, C., Liu, K., Robertson, S., Cook, M. and Collins, C. Open Digital Business Ecosystems: A Pathway for Value Co-Creation. In Proceedings of the 17th International Conference on Informatics and Semiotics in Organisation (ICISO2016) (Campinas, Brazil, 2016)

[21] Harasim, L. M. Learning networks: A field guide to teaching and learning online. MIT press, 1995.

[22] Shorfuzzaman, M., Alelaiwi, A., Masud, M., Hassan, M. M. and Hossain, M. S. Usability of a cloud-based collaborative learning framework to improve learners' experience. Computers in Human Behavior, 51 (2015), 967-976.

[23] Resta, P. and Laferrière, T. Technology in support of collaborative learning. Educational Psychology Review, 19, 1 (2007), 65-83.

[24] Laurillard, D. Rethinking university teaching: A conversational framework for the effective use of learning technologies. Routledge, 2013.

[25] Blas, N., Fiore, A., Mainetti, L., Vergallo, R. and Paolini, P. A portal of educational resources: providing evidence for matching pedagogy with technology. Research in Learning Technology, 22, 1 (2014), 22906.

[26] Mitnik, R., Recabarren, M., Nussbaum, M. and Soto, A. Collaborative robotic instruction: A graph teaching experience. Computers \& Education, 53, 2 (2009), 330-342.

[27] Niederman, F., Butler, B. S., Gallupe, R. B., Tan, B. C. and Urquhart, C. Electronic pedagogy and future university business models. Communications of the Association for Information Systems, 38, 1 (2016), 157-170.

[28] Bloom, B. S. Taxonomy of educational objectives. Vol. 1: Cognitive domain. New York: McKay (1956), 20-24.

[29] Hevner, A. R., March, S. T., Park, J. and Ram, S. Design science in information systems research. MIS quarterly, 28, 1 (2004), 75-105.

[30] Fischer, C., Gregor, S. and Aier, S. Forms of discovery for design knowledge. In Proceedings of the 20th European Conference on Information Systems (ECIS2012) (Barcelona, Spain, 2012)

[31] Saunders, M. N., Lewis, P. and Thornhill, A. Research Methods For Business Students (Seventh Edition). Pearson Education Limited, England, 2015.

[32] Elliott, R. and Timulak, L. Descriptive and interpretive approaches to qualitative research. A handbook of research methods for clinical and health psychology (2005), 147-159.

[33] Delone, W. H. and McLean, E. R. The DeLone and McLean model of information systems success: a ten-year update. Journal of management information systems, 19, 4 (2003), 930.

[34] Wentzell, B. Characteristics of A Quality Educational Website. Canadian Teachers Network (CATNET), Oshawa, Canada, 2003.

[35] Davis, F. D. Perceived usefulness, perceived ease of use, and user acceptance of information technology. MIS quarterly (1989), 319-340. 